\title{
LEVEL PENALARAN ALJABAR SISWA DALAM PEMBELAJARAN MATEMATIKA DI SEKOLAH DASAR
}

\author{
Ericha Putri Puspitasari \\ ericha.puspitasari@yahoo.com \\ SDMuhammadiyah Purworejo
}

\begin{abstract}
This study aims to determine the level of students algebraic reasoning mathematics learning in elementary school. This type of research is qualitative research. The subjects 3 students was fifth grade students of elementary school in Purworejo. The selection of subjects techniques in this study is snowball. Data collection uses learning activities with supporting media in the form of student worksheets, observation sheets, field notes and interviews. Data analysis techniques used from Miles \& Hubermen which include three activities namely data reduction, data presentation, and conclusion drawing. The results of this study indicate that there are activities in mathematics learning that have not entered the level of algebraic reasoning put forward by Godino namely level 1,5. These stages are passed gradually from level 0 to level 3 and passed level 1,5, that is, linking the concept of constructing a square with an algebraic symbol before reaching level 2. Subject activity carried out at this level are more about linking objects with other concepts in mathematics learning..
\end{abstract}

Keywords: algebraic reasoning, level of algebraic reasoning

\begin{abstract}
Abstrak
Penelitian ini bertujuan untuk mengetahui level penalaran aljabar siswa dalam pembelajaran matematika di sekolah dasar. Jenis penelitian adalah penelitian kualitatif. Subjek penelitian ini 3 siswa kelas V sekolah dasar di Purworejo. Teknik pengambilan subjek yang digunakan dalam penelitian ini adalah snowball. Pengumpulan data menggunakan aktivitas pembelajaran dengan media pendukung berupa Lembar Kerja Siswa, lembar observasi, catatan lapangan dan wawancara. Teknik analisis data yang digunakan dari Miles \& Hubermen yang meliputi tiga aktivitas yaitu reduksi data, penyajian data, dan penarikan kesimpulan. Hasil penelitian ini menunjukkan bahwa terdapat aktivitas pada pembelajaran matematika yang belum masuk pada level penalaran aljabar yang dikemukakan oleh Godino yaitu level 1,5. Tahapan tersebut terlewati secara bertahap dari level 0 sampai level 3 dan melewati level 1,5 yaitu mengaitkan konsep bangun persegi dengan simbol aljabar sebelum sampai pada level 2. Aktivitas subjek yang dilakukan pada level ini lebih pada pengkaitan objek dengan konsep lain dalam pembelajaran matematika.
\end{abstract}

Kata kunci: penalaran aljabar, level penalaran aljabar 


\section{PENDAHULUAN}

Kemampuan penalaran merupakan salah satu dari sekian banyak kecerdasan yang harus dimiliki dan dikuasai siswa saat mempelajari matematika. Kemampuan penalaran juga bagian yang tidak terpisahkan dari pembelajaran matematika. Sebagaimana diungkapkan NCTM (2000) bahwa, "reasoning is an integral part of doing mathematics. Students should enter the middle grades with the view that mathematics involves examining patterns and nothing regularities, making conjectures about possible generalizations, and evaluating the conjectures". Dengan memiliki kemampuan penalaran matematika yang baik, siswa mampu melakukan kegiatan memeriksa pola dan keteraturan mencatat, membuat dugaan tentang kemungkinan generalisasi, dan mengevaluasi dugaan.

Aljabar adalah suatu cara berpikir, suatu kumpulan konsep, dan keterampilan yang memungkinkan siswa melakukan generalisasi, memodelkan, dan menganalisis situasi matematika (NCTM dalam Nuraini dkk, 2016). Data Trends in International Mathematics and Science Study (TIMSS, 2011) terhadap siswa SMP Indonesia pada domain materi rata-rata presentase paling rendah pada kemampuan aljabar yaitu $22 \%$ (Rosnawati dalam Nuraini dkk, 2016; Yekti dkk, 2016). Hal ini menunjukkan bahwa kemampuan penalaran aljabar siswa masih rendah dan perlu dikaji lebih dalam tentang level penalaran aljabar ini. Penelitian sebelumnya yang dilakukan oleh Hunter dan Anthony (dalam Nuraini dkk, 2016) telah menjelaskan bahwa kemampuan penalaran aljabar siswa, pada subjek siswa yang berusia 9 s.d. 11 tahun, siswa mengalami kesulitan dalam mengembangkan pemahamannya pada konsep aljabar. Hal ini menunjukkan bahwa pemahaman konsep aljabar siswa masih sulit untuk diungkapkan atau dikomunikasikan. Penelitian ini berkaitan dengan penalaran aljabar siswa terutama pada siswa sekolah dasar. Melatih penalaran siswa dapat dilakukan dengan membiasakan diri siswa memecahkan masalah-masalah matematika terutama dalam pembelajaran geometri. Dalam pembelajaran matematika, siswa dibiasakan untuk memperoleh pemahaman melalui pengalaman tentang sifat-sifat yang dimiliki dan tidak dimiliki oleh sekumpulan objek (abstraksi) (Syaharuddin, 2016). Jadi siswa diharapkan dapat memahami dan bernalar dalam pembelajaran matematika.

Pembelajaran geometri dapat meningkatkan kemampuan matematika siswa. Salah satu tujuan dari belajar geometri adalah untuk mengembangkan keterampilan 
pemecahan masalah dengan menggunakan pemikiran logis dan matematis (Suherman dalam Suwito, 2016). Bila aktivitas-aktivitas tersebut dapat dilakukan dengan benar dan kegiatan pemecahan masalah ini selalu diintegrasikan pada setiap pembelajaran matematika terutama geometri, maka secara perlahan kompetensi penalaran siswa dapat ditingkatkan (Sukayasa, 2009). Dalam penelitian ini, diharapkan mampu merangsang siswa untuk lebih akurat menemukan sifat atau ketentuan ukuran sisi untuk membentuk bangun geometri kemudian diekspresikan dalam bentuk aljabar. Hal ini menunjukkan bahwa geometri berkaitan erat dengan aljabar (Suwito, 2016).

Hasil penelitian yang dikemukakan oleh Mistretta (dalam Riyanto, 2011) dalam penalaran materi geometri juga, menyatakan bahwa "carroll found that junior high and senior high school students often lacked experience in reasoning about geometric ideas". Pernyataan tersebut menunjukkan bahwa penalaran siswa dalam ide geometri masih kurang.dan perlu peningkatan kemampuan penalaran siswa di sekolah dasar dan menengah. Peningkatan kemampuan penalaran ini dapat diatasi dengan menjalin diskusi antar teman ataupun siswa dengan guru. Dalam penelitian ini, peneliti ingin mengetahui level penalaran aljabar siswa dalam pembelajaran matematika terutama pada materi geometri bidang di sekolah dasar. Level penalaran aljabar tersebut sebagai acuan untuk aktivitas pembelajaran matematika siswa sekolah dasar yang seharusnya dicermati mulai dari proses memahami masalah.

\section{PENALARAN ALJABAR}

Menurut De Walle dkk (dalam Ontario Ministry of Education, 2013) penalaran aljabar melibatkan pembentukan generalisasi dari pengalaman dengan jumlah dan perhitungan, memformalkan gagasan ini dengan menggunakan sistem simbol yang berarti, dan mengeksplorasi konsep pola dan fungsi. Dari pendapat di atas mengatakan bahwa penalaran aljabar merupakan aktivitas menggeneralisasikan perhitungan dengan menggunakan simbol dan konsep pola aljabar. Sehingga dalam penelitian ini, peneliti mengasumsikan bahwa penalaran aljabar merupakan aktivitas menggeneralisasikan ide matematika yang berkaitan dengan aljabar menuju suatu kesimpulan sesuai dengan pengalaman, konsep matematika terutama pola aljabar, serta dapat menyajikan dalam bentuk simbol, berupa huruf dan persamaan/model matematika yang saling berkaitan.

Penalaran aljabar dapat diklasifikasikan dalam beberapa level, level penalaran 
aljabar yang dimaksud dalam penelitian ini yaitu alat yang digunakan untuk mengukur tingkat penyelesaian dalam memecahkan masalah aljabar. Godino dkk (2016) menyatakan bahwa tingkat penalaran dibagi menjadi enam tingkat berikut penalaran aljabar dalam pendidikan dasar dan menengah (mulai level 0 sampai dengan level 6) yaitu: a) level 0: operasi dengan benda-benda tertentu menggunakan benda alami (asli), numerik, bahasa gestural dilakukan, b) level 1: penggunaan objek intensif, sifat-sifat struktur aljabar dari $N$ dan kesetaraan aljabar (kesetaraan), c) level 2: penggunaan simbolik numerik mewakili keadaan permasalahan, meskipun terkait dengan informasi spasial, temporal dan kontekstual, memecahkan persamaan dari bentuk $A x \pm B=C$, d) level 3: simbol yang digunakan analitis, tanpa mengacu pada informasi kontekstual. Operasi dengan jumlah tak tentu atau variabel dilakukan, e) level 4: mempelajari tentang persamaan dan fungsi menggunakan parameter dan koefisien f) level 5: Analytical (sintaksis) perhitungan dilakukan melibatkan satu atau lebih parameter, g) level 6: Studi struktur aljabar, definisi dan sifat struktural.

Pada penelitian ini, peneliti menduga terdapat suatu aktivitas pada level diantara level 1 dan level 2, yaitu aktivitas pengkaitan objek intensif dengan konsep lain (simbol aljabar). Pada aktivitas ini siswa dapat menuliskan simbol aljabar apabila telah memahami objek-objek secara berulang dan dapat memahami konsep yang berkaitan dengan aljabar. Pada penelitian ini aktivitas pembelajaran yang dilakukan berdasarkan level penalaran aljabar dan peneliti kembangkan yang mengacu pada teori penalaran aljabar yang dikemukakan oleh Godino dkk. Dalam penelitian ini hanya dilakukan pada siswa sekolah dasar dan pelevelan yang digunakan yaitu pada level 0 sampai dengan level 3.

\section{METODE PENELITIAN}

Jenis penelitian ini adalah penelitian kualitatif dan menggunakan pendekatan grounded theory. Subjek dalam penelitian ini adalah 7 siswa kelas VI sekolah dasar di Kabupaten Purworejo. Teknik pengambilan data yang digunakan adalah pembelajaran matematika dengan media pendukung Lembar Kerja Siswa (LKS) yaitu berupa aktivitas pembelajaran matematika dengan materi keliling dan luas persegi, persegi panjang. Selain itu, pengumpulan data yang digunakan yaitu lembar observasi, catatan lapangan dan wawancara. Data yang sudah diperoleh kemudian dianalisis. Analisis data yang 
digunakan yaitu menggunakan teknik analisis yang dikemukakan oleh Miles \& Huberman (dalam Sugiyono, 2016). Adapun langkah analisis data yang dimaksud meliputi reduksi data, penyajian data, dan penarikan kesimpulan. Teknik triangulasi digunakan untuk memperkuat data-data yang diperoleh, maka data dapat dicocokkan dari hasil jawaban LKS, wawancara, catatan lapangan dan lembar observasi.

\section{HASIL DAN PEMBAHASAN}

Berdasarkan hasil penelitian, peneliti menemukan ada suatu aktivitas dalam menyelesaikan masalah matematika yang tidak masuk dalam level penalaran aljabar Godino. Langkah pertama yang dilakukan $S_{c}$ saat mengikuti pembelajaran matematika. Berikut aktivitas pembelajaran yang terlihat saat menggambarkan bangun persegi.

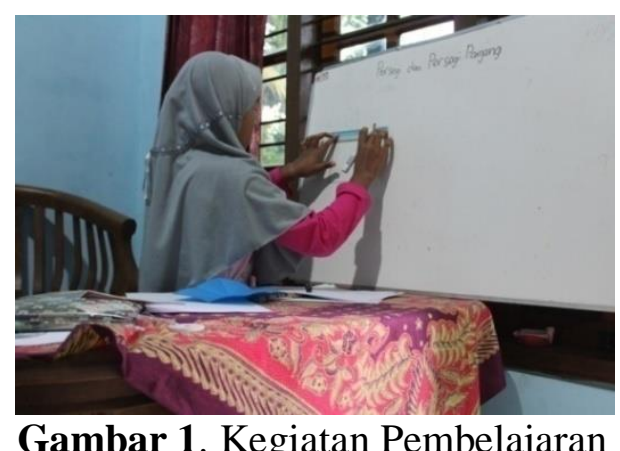

Gambar di atas menunjukkan bahwa $S_{c}$ dapat menggambarkan bangun persegi dengan tepat pada papan tulis. Selain itu, $S_{c}$ mampu menggunakan penggaris untuk mengukur panjang sisi-sisinya. Hal tersebut menunjukkan bahwa aktivitas yang menandakan $S_{c}$ bernalar dalam pembelajaran matematika. Aktivitas lainnya, yang menunjukkan bernalar yaitu pada saat peneliti bertanya contoh benda yang berbentuk persegi, $S_{c}$ menjawab dengan benar dan dapat menyebutkan sisinya yang sama panjang. Aktivitas pembelajaran sudah terlaksana, kemudian dilanjutkan dengan pengerjaan LKS.

Langkah selanjutnya yang dilakukan $S_{c}$ setelah membaca perintah LKS, kemudian $S_{c}$ mulai mengisi sesuai dengan pengetahuan yang ia ketahui. Aktivitas selanjutnya yaitu penemuan objek alami yang terdapat pada lingkungan sekitar. $S_{c}$ mencari benda yang berbentuk persegi dan persegi panjang. Berkut lembar jawab LKS yang menunjukkan bahwa $S_{c}$ memahami benda-benda alami yang ditemukan pada lingkungan sekitar. 


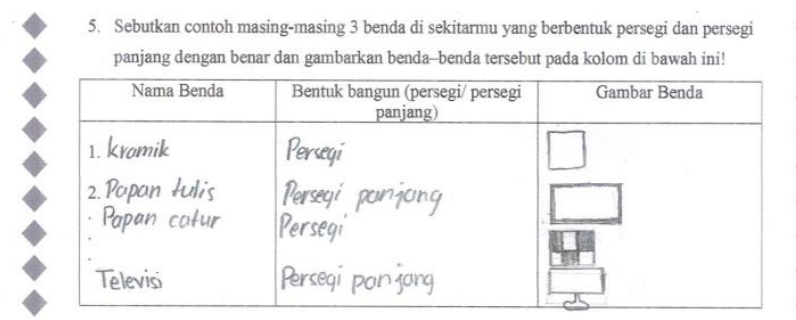

Gambar 2. Lembar Jawab LKS

Gambar di atas menunjukkan bahwa $S_{c}$ tidak menggolongkan yang bangun persegi ataupun persegi panjang dahulu, tetapi $S_{c}$ menuliskan yang ia ketahui terlebih dahulu. Sesuai jawaban LKS di atas dapat diketahui bahwa $S_{c}$ sudah melewati level 0 yaitu operasi benda-benda alami. Selanjutnya, aktivitas yang dilakukan yaitu pengerjaan LKS bagian mengenal sifat-sifat bangun persegi dan persegi panjang. Data yang diperoleh saat pengerjaan tersebut yaitu menggunakan wawancara. Berikut cuplikan wawancara yang menyajikan data tersebut.

\begin{tabular}{|ll|}
\hline P: & "Bagaimana cara menjawab sifat-sifat persegi dan persegi panjang? \\
& Apakah kamu hanya mengingat-ingat sifat-sifatnya atau menggunakan \\
& benda yang berbentuk persegi/ persegi panjang?"
\end{tabular}

Berdasarkan wawancara di atas, $S_{c}$ dapat memahami dengan mudah menggunakan alat bantu yang ada. Sesuai data yang diperoleh, $S_{c}$ paham sifat-sifat bangun persegi dan pesegi panjang. Melalui aktivitas di atas dapat diketahui penalaran aljabar pada level 1 yaitu penggunaan objek intensif beserta sifat-sifatnya. Dapat dikatakan $S_{c}$ merupakan siswa yang memiliki kemampuan berpikir dan bernalar dengan baik. Hal tersebut juga dapat diketahui pada data observasi yang menunjukkan bahwa dia bisa membayangkan benda-benda tersebut menggunakan bahasa tubuhnya. Aktivitas berikutnya pada pengerjaan LKS yang melakukan aktivitas menggambar sebuah persegi. $S_{c}$ menunjukkan bahwa dia dapat menggambarkan bangun persegi yang sesuai dan memiliki ukuran sisi yang sesuai. Selain itu, $S_{c}$ dapat mengaitkan antar konsep satu bangun persegi dan melakukan aktivitas selanjutnya yaitu menggabungkan dua buah bangun persegi yang membentuk bangun persegi panjang. Aktivitas ini menunjukkan keterkaitan konsep bangun persegi dan simbol aljabar pada pemahaman bangun persegi yang diberi nama dengan suatu huruf. Berikut ini lembar jawab yang menunjukkan aktivitas penggabungan suatu persegi dan persegi lainnya dengan ukuran 
yang sama.

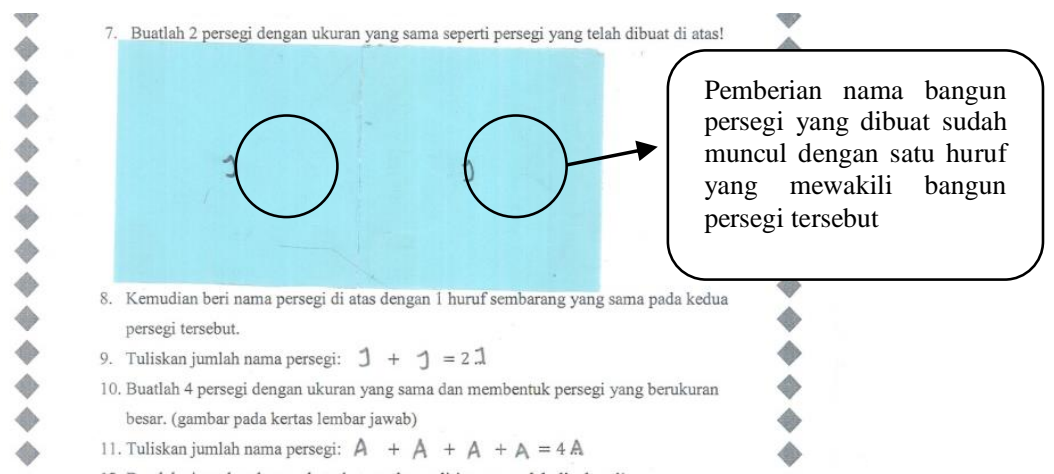

Gambar 3. Lembar Jawab LKS

Berdasarkan jawaban $S_{c}$ menunjukkan bahwa persegi yang memiliki ukuran yang sama jika digabungkan akan menjadi bangun persegi panjang. Serta dalam persegi tersebut diberi nama dengan suatu simbol yaitu huruf "J". Selain itu $S_{c}$ sudah tepat menjumlahkan nama persegi yang ia berikan. Penjumlahan nama-nama bangun persegi yang telah $S_{c}$ buat merupakan aktivitas penggunaan simbol yang mewakili persegi satuan tersebut. Hal tersebut menunjukkan bahwa $S_{c}$ dapat dikatakan termasuk pada level 2 penalaran aljabar. Aktivitas berikutnya yaitu penggambaran persegi satuan dengan penggabungan empat persegi pada aktivitas nomor 10 .

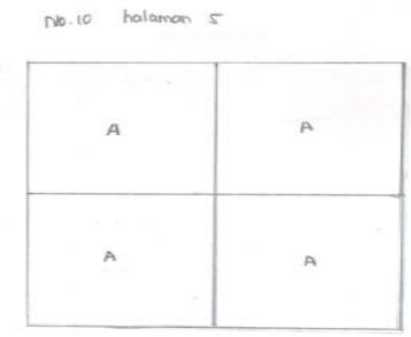

Gambar 4. Lembar Jawab LKS

Diperoleh gambar persegi yang berukuran lebih besar dan tersusun dari empat persegi satuan. Hal tersebut sudah sesuai dan tepat, serta sudah dituliskan simbol nama perseginya pada masing-masing persegi. Jadi $S_{c}$ sudah dapat dikatakan memenuhi level 2 penalaran aljabar dalam pembelajaran matematika. Selain aktivitas tersebut, kemudian langkah berikutnya yaitu menuliskan simpulan dari aktivitas yang telah dilakukan $S_{a}$, meskipun simpulan yang tertulis belum secara lengkap. Tetapi $S_{a}$ sudah dapat berani menuliskan simpulan yang ia pahami. Hanya saja untuk kesimpulan dia hanya menyimpulkan sifat-sifat bangun persegi saja bukan kesimpulan yang sesuai aktivitas sebelumnya. Untuk mengetahui level berikutnya berarti dapat dilihat pada lembar jawab LKS berikut ini. 

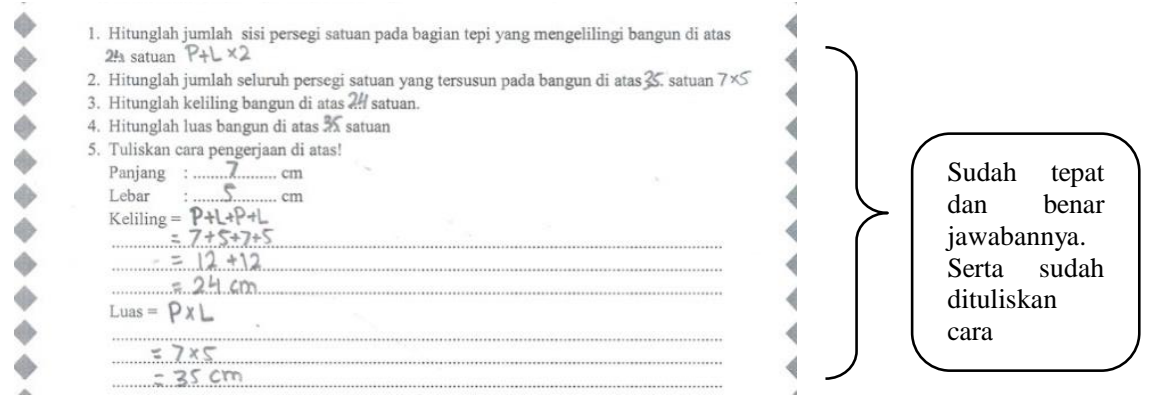

Gambar 5. Lembar Jawab LKS

Dari gambar di atas dapat diketahui bahwa $S_{c}$ mampu memahami perintahperintah pada LKS yang mengarahkan siswa untuk menuju aktivitas penalaran aljabar siswa pada materi geometri ini untuk materi persegi dan persegi panjang. Adapun data yang diperoleh melalui LKS di atas menunjukkan $S_{c}$ memahami konsep persegi dan persegi panjang serta sudah memenuhi level 3 penalaran aljabar yaitu pengoperasian simbol yang telah digunakan pada sebelumnya dengan tepat dan dapat bernalar melalui perintah-perintah yang terdapat pada lembar terakhir LKS penalaran aljabar tersebut.

Berdasarkan paparan hasil analisis LKS dan aktivitas pembelajaran, terlihat bahwa subjek telah melewati level penalaran aljabar dalam pembelajaran matematika di sekolah dasar. Level ini terjadi secara bertahap dari level 0 (operasi benda-benda tertentu yang terdapat pada lingkungan sekitar) sampai dengan level 3 (pengoperasian simbol yang telah dibuat sebelumnya sesuai perintah yang telah diketahui). Tahapan tersebut terlewati secara betahap dari level 0 sampai dengan level 3 dan melewati level 1,5 yaitu mengaitkan konsep bangun persegi satuan dengan simbol aljabar sebelum sampai pada level 2. Jadi dapat disimpulkan bahwa ada suatu aktivitas pada saat pembelajaran matematika (persegi dan persegi panjang) yang belum masuk pada level penalaran aljabar yang dikemukakan oleh Godino yaitu level 1,5. Aktivitas subjek yang dilakukan pada level ini lebih pada pengkaitan objek dengan konsep lain dalam pembelajaran matematika.

\section{SIMPULAN DAN SARAN}

Berdasarkan hasil analisis data penelitian mengenai level penalaran aljabar siswa dalam pembelajaran matematika di sekolah dasar, siswa SD telah memenuhi level 0 
sampai dengan level 3. Namun, terdapat suatu aktivitas yang dilakukan siswa ketika proses pembelajaran yaitu pada aktivitas mengaitkan bangun segi empat dengan konsep lain, yaitu simbol aljabar. Sehingga tahapan ini digolongkan pada suatu level yang terletak diantara level 1 dan level 2 yaitu level 1,5 (pengkaitan objek intensif dengan konsep lain). Saran dari penelitian ini untuk penelitian selanjutnya yaitu dapat menggunakan materi selain geometri yang relevan untuk mengetahui apakah level baru ini berlaku pada materi selain geometri bangun persegi dan persegi panjang. Serta diharapkan dapat menemukan level baru pada tingkat sekolah menengah ataupun yang lebih tinggi.

\section{DAFTAR PUSTAKA}

Godino, J. D., Neto, T., Wilhelmi, M., Ake, L., Etchegaray, S., \& Lasa, A. 2016. Algebraic Reasoning Levels In Primary And Secondary Education. Proceedings Of The Ninth Congress Of The European Society For Research In Mathematics Education. p. 426-432.

NCTM. 2000. Principles and Standars for School Mathematics. USA: The National Council of Teachers of Mathematics, Inc.

Nuraini, L., Sujadi, I., \& Subandi, S. 2016. Penalaran Aljabar Siswa Kelas VII SMP Negeri 1 Margoyoso Kabupaten Pati dalam Pemecahan Masalah Matematika Tahun Pelajaran 2014/2015. Jurnal Elektronik Pembelajaran Matematika. Vol. 4, No. 6: 674-683.

Ontario Ministry of Education. 2013. Paying Attention to Algebraic Reasoning. Toronto, ON: Queen's Printer for Ontario.

Riyanto, B., \& Siroj, R. A. 2011. Meningkatkan Kemampuan Penalaran dan Prestasi Matematika dengan Pendekatan Konstruktivisme pada Siswa Sekolah Menengah Atas. Jurnal Pendidikan Matematika. Vol.5, No. 2: 111-128.

Sugiyono. 2016. Metode Penelitian Pendidikan Pendekatan Kuantitatif, Kualitatif, dan $R n D$. Bandung: Alfabeta.

Sukayasa. 2009. Penalaran dan Pemecahan Masalah dalam Pembelajaran Geometri. Prosiding Seminar Nasional Penelitian, Pendidikan dan Penerapan MIPA, Fakultas MIPA, Universitas Negeri Yogyakarta. hlm. 545-552.

Suwito, A., Yuwono, I., Parta, I. N., Irawati, S., \& Oktavingtyas E. 2016. Solving Geometric Problems by Using Algebraic Representation for Junior High School Level 3 in Van Hiele at Geometric Thinking Level. International Education Studies. Vol. 9, No. 10: 27-33. 
Syaharuddin. 2016. Deskripsi Kemampuan Pemecahan Masalah Matematika dalam Hubungannya dengan Pemahaman Konsep Ditinjau dari Gaya Belajar Siswa Kelas VIII SMPN 4 Binamu Kabupaten Jeneponto.Tesis tidak dipublikasikan. Program Pascasarjana Universitas Negeri Makassar.

Yekti, S. M. P., Kusmayadi, T. A., \& Riyadi. 2016. Penalaran Matematis Siswa dalam Pemecahan Masalah Aljabar Ditinjau dari Gaya Kognitif Field Dependent-Field Independent. Journal Mathematic Education. Vol. 6, No. 2: 178-192. 